Article

\title{
Global Methylation and Protamine Deficiency in Ram Spermatozoa Correlate with Sperm Production and Quality but Are Not Influenced by Melatonin or Season
}

\author{
Kelsey R. Pool * (1), Jessica P. Rickard and Simon P. de Graaf \\ Faculty of Science, School of Life and Environmental Sciences, The University of Sydney, \\ Sydney, NSW 2006, Australia; jessica.rickard@sydney.edu.au (J.P.R.); simon.degraaf@sydney.edu.au (S.P.d.G.) \\ * Correspondence: kelsey.pool@uwa.edu.au; Tel.: +61-434-148-017
}

Received: 2 November 2020; Accepted: 3 December 2020; Published: 4 December 2020

check for updates

Simple Summary: Though environmental factors can alter the epigenome of mammalian spermatozoa, it is currently unclear whether these epigenetic changes are linked to sperm production, quality and fertility. This study aimed to identify whether the hormone melatonin, responsible for upregulating ram reproductive function, is able to alter broad epigenetic markers in spermatozoa, namely sperm global methylation and protamine deficiency. It was also investigated whether these parameters corresponded to ram endocrinology, semen production and quality. Though no effects of season or melatonin were found, both sperm global methylation and protamine deficiency correlated with several semen production and quality parameters. These moderate associations with sperm production and quality support that sperm protamine deficiency and global methylation are broadly indicative of testicular function.

\begin{abstract}
This study assessed whether the seasonal effects of melatonin that upregulate ram reproductive function alter sperm global methylation or protamine deficiency and whether these parameters corresponded to ram endocrinology, semen production and quality. Ejaculates were assessed from rams that received melatonin implants $(n=9)$ or no implants $(n=9)$ during the non-breeding season. Ejaculates ( $n=2 / \mathrm{ram} /$ week) were collected prior to implantation (week 0 ), 1,6 and 12 weeks post implantation and during the following breeding season (week 30). Flow cytometry was used to assess the sperm global methylation and protamine deficiency in each ejaculate, which had known values for sperm concentration, motility, morphology, DNA fragmentation, seminal plasma levels of melatonin, anti-Mullerian hormone and inhibin A. Serum levels of testosterone and melatonin were also evaluated. Though there was no effect of melatonin or season, sperm protamine deficiency was negatively correlated with sperm production and seminal plasma levels of anti-Mullerian hormone and positively correlated with sperm DNA fragmentation and morphology. Global methylation of spermatozoa was positively correlated with sperm DNA fragmentation, morphology and serum testosterone and negatively correlated with sperm motility. These moderate associations with sperm production and quality suggest that sperm protamine deficiency and global methylation are indicative of ram testicular function.
\end{abstract}

Keywords: melatonin; sperm; protamine; methylation; reproductive seasonality; testicular function

\section{Introduction}

Environmentally induced epigenetic changes in the male gamete are of increasing interest, as they emerge to be key drivers of developmental plasticity across generations [1]. Established 
predominantly in humans and mice, exposure of males to factors such as diet, exercise, pollutants and other environmental cues results in marked changes to the epigenome of spermatozoa [2-5], though the relationship between such changes and sperm fertility is yet to be fully elucidated. These effects upon the sperm epigenome are explored to a far lesser extent in domestic livestock, despite the exposure of males to a range of environmental conditions, stressors and diets in commercial production systems. Of particular interest, seasonal breeders, such as sheep, are dependent upon environmental cues for successful reproduction [6,7] and as such undergo marked seasonal changes. In spite of these fluctuations in reproductive capacity, there is little investigation upon differing epigenetic patterns in ram spermatozoa in response to season.

Ovine reproductive seasonality is primarily regulated by the neurohormone melatonin, secreted in response to photoperiod exposure [8-10]. Whilst ewes entirely cease ovarian activity during the non-breeding season, rams continue to produce spermatozoa [11,12], thus exposing viable sperm cells to a range of differing environmental, and physiological, conditions. Though it is well established that most ram breeds exhibit a reduction in testicular size and sperm production in response to the environmental changes delineating the non-breeding season [11,12], there are many discrepancies concerning seasonal changes in sperm function and fertilising capacity [12-14]. There is thus considerable ambiguity surrounding the practice of collecting semen for artificial insemination during the non-breeding season, as despite negative perceptions, it is unclear if sperm function is truly reduced during this period. Furthermore, though it appears evident that ram testicular function is able to be improved utilising slow-release melatonin implants [8,15-17], thereby increasing sperm production, there are conflicting reports regarding whether melatonin exposure is able to seasonally modulate sperm functionality $[8,16,18,19]$. Regardless of whether reproductive upregulation in the ram occurs naturally or is artificially stimulated, spermatozoa are exposed throughout the spermatogenic cycle to the different endocrine conditions stimulated by melatonin, such as upregulated testosterone production at both a systemic and a testicular level $[15,20]$, as well as to melatonin itself. Given that melatonin is shown to induce functional changes to spermatozoa in an in vitro setting [21-23], and possibly when used exogenously [16], this brings into question as to whether spermatozoa exposed to breeding season conditions have altered function and fertility and if this may be reflected in broad changes to the sperm epigenome.

Broad epigenetic changes within spermatozoa are now known to occur in response to external factors, the resulting epigenetic profiles emerging as being vital to reproductive success [24-26]. One primary mechanism of interest, DNA methylation, is reported to influence sperm development at several stages of the spermatogenic cycle [27-29]. A constantly dynamic process where a methyl group is added to cytosine in $\mathrm{CpG}$ dinucleotides, methylation regulates various cell processes and gene expression $[1,30]$. This reversible epigenetic programming appears to be impacted by several factors local to the testes, including testicular pathologies and endocrine fluctuations. Accordingly, the level of global DNA methylation in human [31,32], boar [33] and rat [34,35] spermatozoa is associated with sperm quality. Cumulatively, such studies suggest that global methylation may be a valuable marker of sperm competence and one that could plausibly be affected by the seasonal and environmental changes encountered in animal production systems.

The DNA of spermatozoa is similarly subjected to external environmental cues and stressors [36]. The corresponding degree of damage appears to be somewhat conditional to the integrity of sperm chromatin, the structural packaging of which is dependent upon protamines [37,38]. Protamines, the primary nuclear proteins of sperm cells, are responsible for packaging sperm chromatin into a semi-crystalline state [37,38]. Mouse models with decreased quantities of protamine proteins demonstrate abnormal sperm morphology, abnormal chromatin packaging, DNA damage and male infertility [39], indicating that sperm protamine deficiency can have detrimental impacts upon male fertility. Though studies in some domestic livestock species support this theory [33,40], there is no investigation of this relationship in the ram, nor any evidence of changes in response to the seasonal upregulation of the reproductive function. 
Whether broad epigenetic changes in spermatozoa occur in response to seasonal cues remains to be elucidated. Accordingly, as sheep have a known mechanism for regulating seasonal reproduction, this study used the ram to investigate whether reproductive seasonality alters global methylation or protamine deficiency in spermatozoa. Here, we investigated whether any alterations existed between the natural breeding and non-breeding periods or if changes were able to be induced by artificially mimicking the onset of the breeding period using slow-release melatonin implants during the non-breeding season. Furthermore, to support the hypothesis that epigenetic changes occur in response to the seasonal upregulation of the reproductive function, we aimed to identify any relationships between sperm global methylation, protamine deficiency and ram endocrinology, semen production and quality.

\section{Materials and Methods}

\subsection{Animals}

This study was carried out in strict accordance with the Australian Research Act 1985 No. 123 and the Australian code for the care and use of animals for scientific purposes 8th edition (2013). All experimental procedures were conducted with approval from the University of Sydney Animal Ethics Committee (approval 2017/1155).

All animals were housed at the University of Sydney Sheep Research Unit, Cobbitty NSW, Australia. Poll Dorset $(n=9)$ and Merino $(n=9)$ rams were maintained as a single mob on pasture. Rams had access to improved pasture (Elymus repens, Pennisetum clandestinum, Themeda triandra, Lolium, Cytisus scoparius, Arrhenatherum elatius, Triticosecale) and water ad libitum. Additional lucerne and lupins were supplemented up to three times a week. All rams were approximately 2 years of age, considered of standard reproductive health (testicular size within normal range, no lesions, no morphological abnormalities of the external reproductive anatomy) and within a normal body condition score range (between 3 and 4) throughout the study period.

\subsection{Experimental Design}

Following an initial two weeks of data collection during the non-breeding season (September), approximately half the rams in each breed were randomly allocated to a treatment group, where they either received $3 \times 18 \mathrm{mg}$ melatonin implants (Regulin, CEVA Animal Health, Australia, Merino = 5, Poll Dorset $=4$ ) or underwent the same implantation process with empty implanter guns to act as a control group (Merino $=5$, Poll Dorset $=4$ ). Treatment groups were balanced for animal weight.

Two ejaculates were collected from each ram once per week throughout the non-breeding season (September-December) and in the following breeding season (April). Samples selected for inclusion in the present study were chosen retrospectively following the completion of a previous study [15]. The study weeks selected for inclusion were week 0 (prior to implantation), week 1 (1 week post implantation), week 6, week 12 and week 30 (the following breeding season). For correlations between sperm protamine deficiency and global methylation and ejaculate quality, the ejaculate (total $n=180$ ) was considered the experimental unit.

\subsection{Semen Collection and Preparation}

Ejaculates were collected from rams using an artificial vagina in the presence of a teaser ewe. For correlation purposes, the following parameters for each ejaculate were established prior to the present study [15]: melatonin concentration in seminal plasma, anti-Mullerian hormone (AMH) concentration in seminal plasma, inhibin A concentration in seminal plasma, ejaculate concentration, ejaculate volume, the number of spermatozoa per ejaculate, sperm motility, the percentage of abnormal spermatozoa and sperm DNA fragmentation. The concentration of testosterone and melatonin in blood serum was also obtained during the same study weeks as ejaculate collections. 
Spermatozoa were isolated from seminal plasma by centrifugation of the whole ejaculate at $14,000 \mathrm{~g}$ for $10 \mathrm{~min}$ and removal of the supernatant. This process was undertaken twice to ensure seminal plasma was absent from the pelleted sperm cells. Spermatozoa were snap-frozen and stored in liquid nitrogen until analysis.

\subsection{Chemicals}

Unless otherwise stated, all chemicals were sourced from Sigma- Aldrich (St Louis, MO, USA). Anti-5-methylcytosine (5-mC) antibody and donkey anti-mouse IgG H\&L (FITC) were purchased from Abcam (Abcam Australia Pty Ltd., Melbourne, Victoria, Australia), and propidium iodide (PI) was sourced from Invitrogen (Thornton, NSW, Australia).

\subsection{Flow Cytometry}

Spermatozoa were assessed using a CytoFLEX flow cytometer (Beckman Coulter, Lane Cove, Australia). Sperm cells were isolated from total events based on forward and side-scatter profiles. The concentration of spermatozoa in the assessed samples was between 2 and $5 \times 10^{6}$ spermatozoa $/ \mathrm{mL}$, and a total of 10,000 spermatozoa per sample were recorded. Samples were analysed using CytExpert 2.0 software (Beckman Coulter, Lane Cove, Australia).

\subsubsection{Protamine Deficiency}

The samples were assessed for protamine deficiency as previously described [33,41], with some adjustments. Snap-frozen samples were thawed on ice, and an aliquot diluted to approximately $2 \times 10^{6}$ sperm cells in $200 \mu \mathrm{L}$ of $1 \times$ TNE buffer $(0.15 \mathrm{M} \mathrm{NaCl}, 0.01 \mathrm{M}$ Tris $\mathrm{HCl}, 1 \mathrm{mM}$ disodium EDTA $\mathrm{pH}$ 7.4). The samples were then washed once in $1 \times \mathrm{TNE}$ (300 $\mathrm{g}$ for $10 \mathrm{~min}$ ) and resuspended in $100 \mu \mathrm{L}$ of McIlvaine's buffer ( $17 \mathrm{~mL} 0.1 \mathrm{~mol} / \mathrm{L}$ citric acid mixed with $83 \mathrm{~mL} 0.2 \mathrm{~mol} / \mathrm{L} \mathrm{Na}{ }_{2} \mathrm{HPO}_{4}$ and $10 \mathrm{mmol} / \mathrm{L}$ $\mathrm{MgCl}_{2}$, pH 7.0) containing $0.25 \mathrm{mg} / \mathrm{mL}$ chromomycin $\left(\mathrm{CMA}_{3}\right)$. The cells were stained for $20 \mathrm{~min}$ and then counterstained with PI at a final concentration of $6 \mu \mathrm{M}$ for $10 \mathrm{~min}$ to assist with the gating of the sperm population.

$\mathrm{CMA}_{3}$ fluorescence from the gated cells was obtained through a 528/45 bandpass filter after excitation with a violet laser $(405 \mathrm{~nm})$. The degree of protamine deficiency was assessed by recording the median $\mathrm{CMA}_{3}$ fluorescence of the sperm population.

\subsubsection{Global Methylation}

The samples were assessed for global methylation as previously described [42,43], with some adjustments. Snap-frozen samples were thawed on ice, and an aliquot adjusted to approximately $5 \times 10^{6}$ sperm cells in $200 \mu \mathrm{L}$ of $1 \times$ TNE buffer $(0.15 \mathrm{M} \mathrm{NaCl}, 0.01 \mathrm{M}$ Tris $\mathrm{HCl}, 1 \mathrm{mM}$ disodium EDTA $\mathrm{pH}$ 7.4). All following steps were performed at room temperature.

To decondense sperm DNA, the samples were incubated for $20 \mathrm{~min}$ in $1 \mathrm{~mol} / \mathrm{L}$ hydrochloric acid ( $\mathrm{HCl}$-Tris buffer, $\mathrm{pH}$ 9.5, containing $25 \mathrm{mmol} / \mathrm{L}$ dithiothreitol. The samples were then washed twice (300 $\mathrm{g}$ for $10 \mathrm{~min}$ ) in phosphate-buffered saline containing 0.5\% Tween (PBS-T 0.5\%). Spermatozoa were then incubated with $\mathrm{HCl}(6 \mathrm{~N})$ for $15 \mathrm{~min}$ to denature sperm DNA. The samples were again washed twice, firstly with a Tris solution $(1 \mathrm{~mol} / \mathrm{L}, \mathrm{pH} 9)$ and then in PBS-T $0.5 \%$. Following this, the samples were incubated with the mouse anti-5-mC antibody at $1 \mu \mathrm{g} / \mathrm{mL}$ in PBS-T $0.5 \%$ for $20 \mathrm{~min}$. The samples were washed twice with PBS-T $0.5 \%$ to remove any excess antibody. The washed samples were then incubated with anti-mouse antibodies conjugated with fluorescein isothiocyanate (FITC) for $20 \mathrm{~min}$ before being counterstained with PI at a final concentration of $6 \mu \mathrm{M}$ for $10 \mathrm{~min}$, to assist with the gating of the sperm population.

Green fluorescence, representing the methylation level, was obtained through a 533/30 nm band-pass filter after excitation with a blue $(488 \mathrm{~nm})$ laser. The level of methylation was determined by recording the median FITC fluorescence of the sperm population. 


\subsection{Statistical Analysis}

All statistical analysis was undertaken using Genstat (version 18, VSN International).

Correlations between global methylation, protamine deficiency and all other parameters were investigated by assessing associations using linear regression. If significant $(p<0.05)$, the Spearman nonparametric correlation test was then used to determine correlations between variables, using two-tailed $p$ values. Correlations were considered significant if $p<0.05$.

To determine any effect of the melatonin treatment, linear mixed-model regression (REML) was used. For the layout of these models, study week, treatment and breed were set as fixed effects, and ram, breed and ejaculate were set as random effects. Normality and homogeneity of residual variances were confirmed using the Shapiro-Wilk test and the Bartlett's test, respectively.

\section{Results}

\subsection{Protamine Deficiency}

As shown in Figure 1, linear mixed models demonstrated no significant difference in sperm protamine deficiency between melatonin and control treatment groups $(p>0.05)$ or study weeks, though in study week 30 (breeding season), protamine deficiency tended to be lower compared to the non-breeding season weeks for all rams, regardless of treatment group $(p=0.074)$. Sperm protamine deficiency was not correlated with levels of melatonin in the seminal plasma or blood $(p>0.05)$.

A)

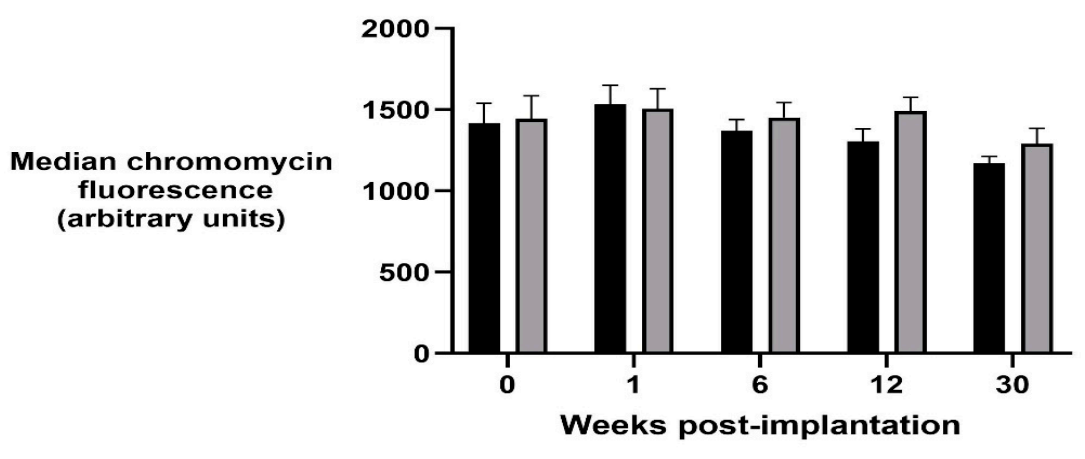

B)

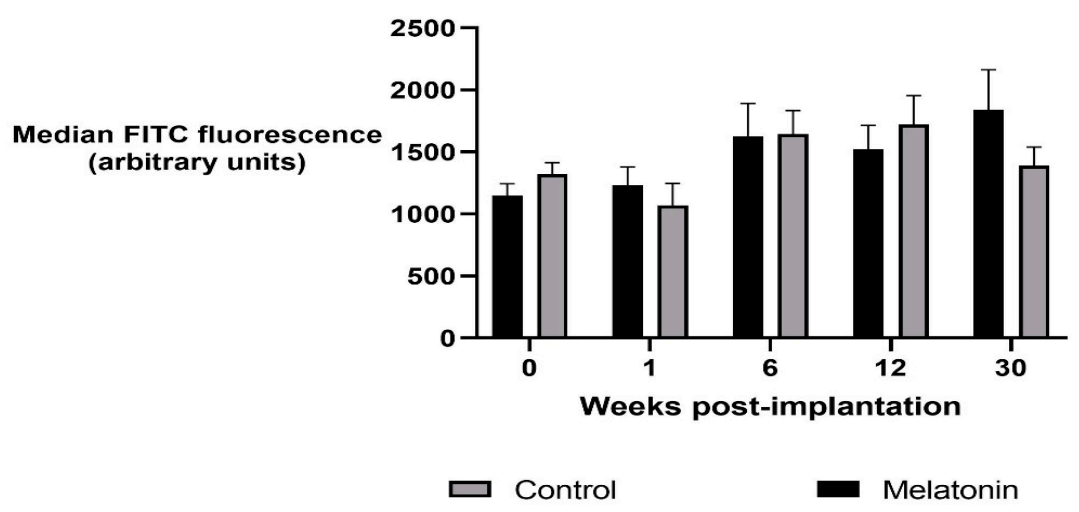

Figure 1. The relative levels of sperm protamine deficiency (A) and global methylation of the sperm epigenome (B) in ejaculates collected from melatonin-treated and control rams over the study period. Changes in protamine deficiency (A) and global methylation (B) are represented by the median chromomycin and FITC fluorescence of the sperm population, respectively. Values are the mean \pm SEM; no significant difference is reported between treatment groups or study weeks $(p>0.05)$. 
Significant relationships were observed between sperm protamine deficiency and sperm DNA fragmentation, the percentage of morphologically abnormal spermatozoa, the concentration and number of spermatozoa per ejaculate and the level of AMH in seminal plasma, as summarised in Figure 2.
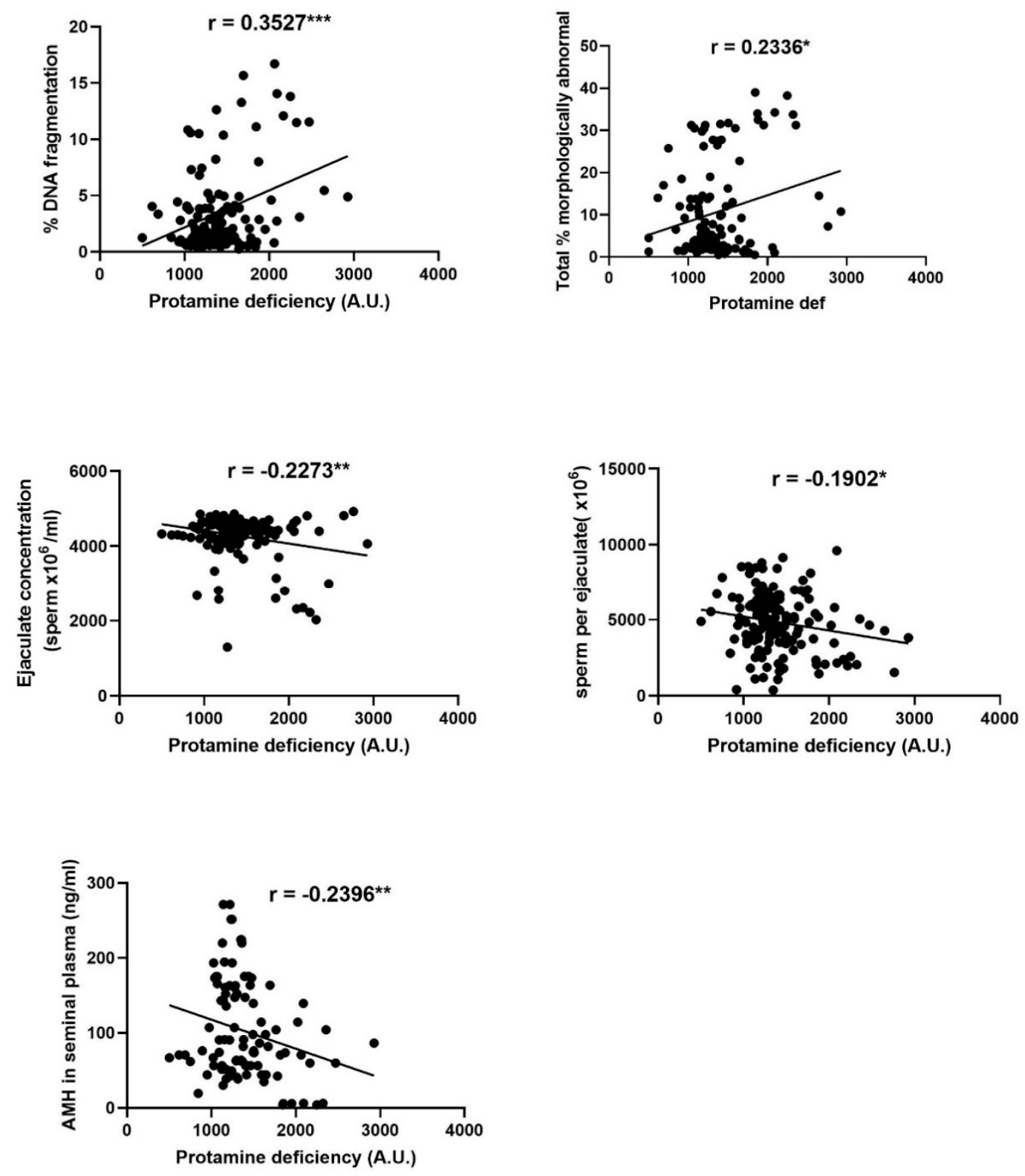

Figure 2. Significant correlations between sperm protamine deficiency and sperm DNA fragmentation, sperm concentration per ejaculate, the number of spermatozoa per ejaculate, anti-Mullerian hormone $(\mathrm{AMH})$ in seminal plasma and the percentage of abnormal spermatozoa. Each data point plotted represents an individual ejaculate. Asterisks indicate the significance of the correlation ${ }^{*} p \leq 0.05$, ** $p \leq 0.01,{ }^{* * *} p \leq 0.001$.

\subsection{Sperm Global Methylation}

Linear mixed models demonstrated no significant difference in the levels of sperm global methylation between treatment groups or study weeks $(p>0.05)$, nor was sperm global methylation correlated with the levels of melatonin in the seminal plasma or blood $(p>0.05)$. 
Significant relationships were observed between levels of global methylation and sperm DNA fragmentation, sperm motility and morphology, and the concentration of testosterone in blood serum, as summarised in Figure 3.
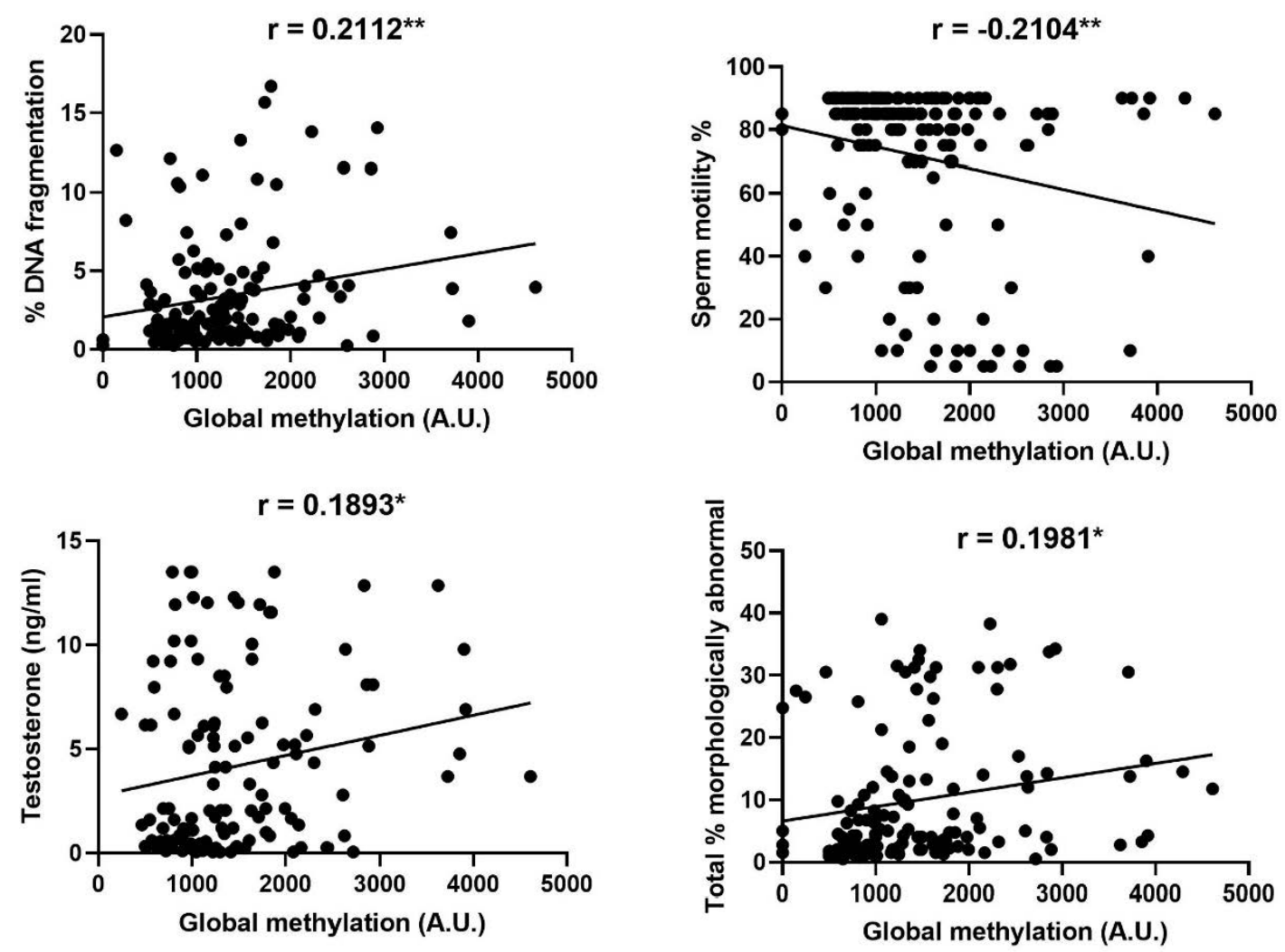

Figure 3. Significant correlations between levels of global methylation in spermatozoa and sperm DNA fragmentation, sperm motility, morphology and the concentration of testosterone in blood serum. Each data point plotted represents an individual ejaculate. Asterisks indicate the significance of the correlation ${ }^{*} p \leq 0.05,{ }^{* *} p \leq 0.01$.

\section{Discussion}

To our knowledge, this is the first study in the ram to characterise relationships between sperm global methylation, protamine deficiency, ram reproductive endocrinology and sperm production and quality. Though some of these correlations have been demonstrated in other species, namely humans [44-46], we show that relationships between epigenetic modifications and semen parameters similarly exist in the ram. Given that epigenetic variations in spermatozoa are now known to occur in response to environmental factors, including changes in nutrition, climate and other external cues [1], we hypothesised that both exogenous melatonin and season would influence the global methylation and protamine status of ram spermatozoa. However, we found no effect of either melatonin or season, despite previously observing differences in ram testicular function in response to melatonin treatment [15]. As the correlations found in the current study were generally only moderately associated, this may account for why melatonin-induced changes to semen parameters were not reflected in patterns of either sperm global methylation or protamine status. Regardless, this study suggests the function of ram spermatozoa is not inferior during the non-breeding period, nor alterations to the broad epigenome are conferred.

In line with previous literature, we found the degree of DNA fragmentation in ram spermatozoa to be positively correlated with both sperm global methylation and protamine deficiency. Given that protamines are an essential part of the sperm DNA packaging process [37,38], the latter result is not unsurprising, this relationship in human spermatozoa having been described in a previous 
meta-analysis [46]. Though it would appear logical that increased DNA fragmentation corresponds to protamine deficiency, the nature of the relationship between these two parameters is far from established. Protamines are ideally present in spermatozoa in a species-specific ratio of protamines 1 and 2, where the replacement of histones with protamines occurs throughout spermatogenesis [47]. Irregular protamine ratios are related to both sperm DNA damage and male sub-fertility [46,48], indicating that protamine status is likely essential for normal embryonic development. Interestingly, though spermatozoa with damaged DNA can display as morphometrically normal and have been reported to maintain fertilisation capacity, this damage may later translate to impaired embryo development following fertilisation [49]. In the present study, the positive correlation between sperm protamine deficiency and DNA fragmentation, but the lack of relationship with sperm functionality, indicates this may indeed represent an issue in the ram. From an industry perspective, spermatozoa that appear functionally normal and are thus used for insemination, only to result in poor embryo development, allow sub-fertile sires to persist in breeding programs, perpetuating poor reproductive efficiency. It is interesting to note that the increase of melatonin, a potent antioxidant [50], in seminal plasma did not decrease the degree of sperm protamine deficiency, as it is theorised that both DNA fragmentation and protamine deficiency are the result of excessive levels of reactive oxygen species (ROS) [46]. Even within our limited sample size, we did observe a trend $(p=0.074)$ describing reduced protamine deficiency during the breeding season. This warrants further study in the ram, as it is currently unclear if and how there are seasonal advantages conferred to mammalian sperm DNA [51,52], though there is some evidence that this occurs in mussels [53].

Though levels of protamine deficiency were not related to sperm function, we did observe correlations to sperm production and morphology, with ejaculates containing lower numbers of spermatozoa and higher percentages of morphologically abnormal spermatozoa having a greater degree of protamine deficiency. Whilst treatment of rams with exogenous melatonin increased sperm production in our previous study [15], we did not similarly see an effect of treatment upon sperm protamine deficiency, possibly due to the assessment of a subset of study weeks in the present study. Regardless, the correlation between sperm protamine deficiency, ejaculate concentration and sperm morphology has been similarly observed in humans [44,45], though to our knowledge this is the first study to suggest that these relationships also exist in the ram. Given that our previous study in the ram established a positive correlation between the number of spermatozoa per ejaculate and AMH concentration in seminal plasma [15], it is interesting to note that seminal plasma levels of $\mathrm{AMH}$ comparably relate to sperm protamine deficiency. In other species, $\mathrm{AMH}$ is an emerging indicator of testicular function, where seminal plasma AMH levels positively correlate with elevated spermatogenesis [54,55], reduced oxidative stress [54,56] and increased semen production [57] and quality [58-62]. In the present study, lower levels of seminal plasma AMH were associated with increased protamine deficiency, supporting the theory that AMH levels in seminal plasma may be somewhat predictive of testicular function.

The methylation of DNA is becoming increasingly investigated in a reproductive context, emerging to have a much more prominent role in sperm functionality than previously assumed. The present study revealed that global methylation in ram spermatozoa is correlated with sperm quality, with ejaculates with lower sperm motility and higher percentages of morphologically abnormal spermatozoa demonstrating greater levels of methylation. There are now several studies suggesting that both patterns and degree of methylation vary between highly and lowly motile sperm populations in the bull [63], normal and sub-fertile men [64-66] and high- and low-fertility buffalo [67]. The correlation between sperm global methylation and semen parameters is less explored in comparison to the relationship between methylation and fertility, with limited previous findings yet to definitively conclude the nature of the association between global methylation and semen parameters. In comparison with the present study, some investigations in human spermatozoa agree that overall hypermethylation is associated with ejaculates of lower motility [68], though others indicate the contrary [65]. As these studies assess human spermatozoa, it cannot be concluded if 
such discrepancies are due to a species-specific difference, variation in the cause of sub-fertility or the different methodologies used to quantify methylation. Regardless of whether sperm populations demonstrate extreme hyper- or hypomethylation, there appears to consistently be a relationship with motility, suggesting that spermatozoa on either end of the methylation spectrum demonstrate impaired motility. Given that sperm motility is a key characteristic used to determine ejaculate fertility in the sheep production industry $[69,70]$, external factors that alter motility are of interest. In this case, we cannot conclude upon any causation behind the relationship between global methylation and sperm motility but can speculate that this may partially be attributed to the other correlations revealed in this study. Inferior quality semen samples are likely to present poor values of the majority of the observed parameters; for example, reduced sperm DNA integrity is often accompanied by lower degrees of motility and normal morphology [71-73]. Here, we similarly saw that methylation was higher in samples with a greater degree of sperm DNA fragmentation and abnormal morphology, and as such the hypermethylation of ram spermatozoa may be related more broadly to poorer quality ejaculates, possibly reflecting altered testicular function, rather than specifically to low sperm motility.

As we did not see any influence of melatonin upon motility in our previous study, it is perhaps unsurprising that neither melatonin concentration in the seminal plasma nor season influenced the global methylation of ram spermatozoa. Curiously, and somewhat contrary to this, we did find a positive correlation between ram serum testosterone and sperm global methylation, though testosterone was increased as a result of melatonin treatment in the previous study [15]. As we found increasing levels of methylation to be mainly associated with poorer semen quality, this result is somewhat unexpected, as greater levels of testosterone have previously been related to upregulated testicular function $[74,75]$. However, it is possible that external factors, such as heat or other stressors, could rapidly influence semen quality and potentially alter sperm DNA methylation, without exerting an effect on testosterone production. This relationship, which was relatively weak despite its statistical significance in the current study, should be clarified under more controlled conditions.

\section{Conclusions}

To conclude, this study found no evidence that either melatonin or season directly exerts an effect upon the global methylation or protamine status of ram spermatozoa. This indicates that, at a broad, non-specific level at least, the epigenome of ram spermatozoa is likely not compromised during the non-breeding season and challenges the negative perceptions surrounding semen collection during this period. However, we did observe relationships between the global methylation and protamine deficiency and ram endocrinology, sperm quality and production, which appear to be consistent with findings in other species. Specifically, the observed associations between protamine deficiency, sperm production, morphology, sperm DNA fragmentation and AMH concentration in seminal plasma suggest that sperm protamine deficiency may indicate testicular function. Similarly, our findings that sperm global methylation is linked to sperm motility, morphology and DNA fragmentation indicate that epigenetics may hold a role in ram sperm functionality, as similarly indicated in humans [65,68], cattle $[63,67]$ and pigs [33]. Our observed correlations warrant further study in the ram in order to clarify the influence of external factors and environmental cues on global methylation and protamine status and to determine any subsequent effects upon fertility.

Author Contributions: Conceptualization, K.R.P., J.P.R. and S.P.d.G.; Formal analysis, K.R.P.; Investigation, K.R.P.; Methodology, K.R.P., J.P.R. and S.P.d.G.; Supervision, S.P.d.G.; Writing-original draft, K.R.P.; Writing -review \& editing, K.R.P., and S.P.d.G. All authors have read and agreed to the published version of the manuscript.

Funding: This research received no external funding.

Conflicts of Interest: Authors declare no conflict of interest. 


\section{References}

1. Donkin, I.; Barrès, R. Sperm epigenetics and influence of environmental factors. Mol. Metab. 2018, 14, 1-11. [CrossRef] [PubMed]

2. Denham, J.; O’Brien, B.J.; Harvey, J.T.; Charchar, F.J. Genome-wide sperm DNA methylation changes after 3 months of exercise training in humans. Epigenomics 2015, 7, 717-731. [CrossRef]

3. Radford, E.J.; Ito, M.; Shi, H.; Corish, J.A.; Yamazawa, K.; Isganaitis, E.; Seisenberger, S.; Hore, T.A.; Reik, W.; Erkek, S.; et al. In utero undernourishment perturbs the adult sperm methylome and intergenerational metabolism. Science 2014, 345, 1255903. [CrossRef] [PubMed]

4. Marcho, C.; Oluwayiose, O.A.; Pilsner, J.R. The preconception environment and sperm epigenetics. Andrology 2019. [CrossRef] [PubMed]

5. Piscopo, M.; Trifuoggi, M.; Notariale, R.; Labar, S.; Troisi, J.; Giarra, A.; Rabbito, D.; Puoti, R.; Brundo, M.V.; Basile, A.; et al. Protamine-like proteins' analysis as an emerging biotechnique for cadmium impact assessment on male mollusk Mytilus galloprovincialis (Lamarck 1819). Acta Biochim. Pol. 2018, 65, 259-267. [CrossRef] [PubMed]

6. Weems, P.W.; Goodman, R.L.; Lehman, M.N. Neural mechanisms controlling seasonal reproduction: Principles derived from the sheep model and its comparison with hamsters. Front. Neuroendocrinol. 2015, 37, 43-51. [CrossRef] [PubMed]

7. Lincoln, G.A.; Clarke, I.J. Photoperiodically-lnduced Cycles in the Secretion of Prolactin in Hypothalamo-Pituitary Disconnected Rams: Evidence for Translation of the Melatonin Signal in the Pituitary Gland. J. Neuroendocrinol. 1994, 6, 251-260. [CrossRef]

8. Rekik, M.; Taboubi, R.; Ben Salem, I.; Fehri, Y.; Sakly, C.; Lassoued, N.; Hilali, E.M. Melatonin administration enhances the reproductive capacity of young rams under a southern Mediterranean environment. Anim. Sci. J. 2015, 86, 666-672. [CrossRef]

9. Kaya, A.; Baspinar, N.; Yildiz, C.; Kurtoglu, F.; Ataman, M.; Haliloglu, S. Influence of melatonin implantation on sperm quality, biochemical composition of the seminal plasma and plasma testosterone levels in rams. Rev. Med. Vet. (Toulouse) 2000, 151, 1143-1146.

10. Rosa, H.; Juniper, D.; Bryant, M. Effects of recent sexual experience and melatonin treatment of rams on plasma testosterone concentration, sexual behaviour and ability to induce ovulation in seasonally anoestrous ewes. J. Reprod. Fertil. 2000, 120, 169-176. [CrossRef]

11. Boland, M.P.; Al-Kamali, A.A.; Crosby, T.F.; Haynes, N.B.; Howles, C.M.; Kelleher, D.L.; Gordon, I. The influence of breed, season and photoperiod on semen characteristics, testicular size, libido and plasma hormone concentrations in rams. Anim. Reprod. Sci. 1985, 9, 241-252. [CrossRef]

12. Belkadi, S.; Safsaf, B.; Heleili, N.; Tlidjane, M.; Belkacem, L.; Oucheriah, Y. Seasonal influence on sperm parameters, scrotal measurements, and serum testosterone in Ouled Djellal breed rams in Algeria. Vet. World 2017, 10, 1486-1492. [CrossRef] [PubMed]

13. Fernandez-Abella, D.; Becu-Villalobos, D.; Lacau-Mengido, I.M.; Villegas, N.; Bentancur, O. Sperm production, testicular size, serum gonadotropins and testosterone levels in Merino and Corriedale breeds. Reprod. Nutr. Dev. 1999, 39, 617-624. [CrossRef] [PubMed]

14. Zamiri, M.J.; Khodaei, H.R. Seasonal thyroidal activity and reproductive characteristics of Iranian fat-tailed rams. Anim. Reprod. Sci. 2005, 88, 245-255. [CrossRef] [PubMed]

15. Pool, K.R.; Rickard, J.P.; Pini, T.; de Graaf, S.P. Exogenous melatonin advances the ram breeding season and increases testicular function. Sci. Rep. 2020, 10, 9711. [CrossRef]

16. Casao, V.S.; Palacin, I.; Perez-Pe, R.; Lavina, A.; Quintin, F.J.; Sevilla, E.; Abecia, J.A.; Cebrian-Perez, J.A.; Forcada, F. Effects of melatonin implants during non-breeding season on sperm motility and reproductive parameters in rasa aragonesa rams. Reprod. Domest. Anim. 2008, 45, 425-432. [CrossRef]

17. Buffoni, A.; Vozzi, A.; Gonzalez, D.M.; Viegas, H.; LaTorraca, A.; Hozbor, F.; Ledesma, A.; Abecia, J.A. Melatonin modifies scrotal circumference but not plasma testosterone concentrations and semen quality of rams during the seasonal anestrus at $43^{\circ} \mathrm{S}$. Biol. Rhythm. Res. 2015, 46, 785-795. [CrossRef]

18. Cevik, M.; Yilmazer, C.; Kocyigit, A. Effects of melatonin implantation on the fertility potentials of Kivircik and Charollais ewes and rams during the non-breeding season. Pol. J. Vet. Sci 2017, 20, 501-506. [CrossRef]

19. Rosa, H.J.D.; Silva, C.C.; Bryant, M.J. The effect of melatonin treatment in rams on seasonal variation of testicular size and semen production parameters. Small Rumin. Res. 2012, 102, 197-201. [CrossRef] 
20. Deng, S.-L.; Wang, Z.-P.; Jin, C.; Kang, X.-L.; Batool, A.; Zhang, Y.; Li, X.; Wang, X.; Chen, S.; Chang, C.; et al. Melatonin promotes sheep Leydig cell testosterone secretion in a co-culture with Sertoli cells. Theriogenology 2018, 106, 170-177. [CrossRef]

21. Succu, S.; Berlinguer, F.; Pasciu, V.; Satta, V.; Leoni, G.G.; Naitana, S. Melatonin protects ram spermatozoa from cryopreservation injuries in a dose-dependent manner. J. Pineal Res. 2011, 50, 310-318. [CrossRef] [PubMed]

22. Casao, A.; Mendoza, N.; Pérez-Pé, R.; Grasa, P.; Abecia, J.A.; Forcada, F.; Cebrian-Perez, J.A.; Muino-Blanco, T. Melatonin prevents capacitation and apoptotic-like changes of ram spermatozoa and increases fertility rate. J. Pineal Res. 2010, 48, 39-46. [CrossRef] [PubMed]

23. Carvajal-Serna, M.; Torres-Ruda, F.; Cardozo, J.A.; Grajales-Lombana, H.; Cebrián-Pérez, J.Á.; Muiño-Blanco, T.; Perez-Pe, R.; Casao, A. Changes in melatonin concentrations in seminal plasma are not correlated with testosterone or antioxidant enzyme activity when rams are located in areas with an equatorial photoperiod. Anim. Reprod. Sci. 2019, 200, 22-30. [CrossRef]

24. Dada, R.; Kumar, M.; Jesudasan, R.; Fernández, J.L.; Gosálvez, J.; Agarwal, A. Epigenetics and its role in male infertility. J. Assist. Reprod. Genet. 2012, 29, 213-223. [CrossRef] [PubMed]

25. Giacone, F.; Cannarella, R.; Mongioì, L.M.; Alamo, A.; Condorelli, R.A.; Calogero, A.E.; La Vignera, S. Epigenetics of male fertility: Effects on assisted reproductive techniques. World J. Men's Health 2019, 37, 148-156. [CrossRef]

26. Kutchy, N.A.; Menezes, E.S.B.; Chiappetta, A.; Tan, W.; Wills, R.W.; Kaya, A.; Topper, E.; Moura, A.A.; Perkins, A.D.; Memili, E. Acetylation and methylation of sperm histone 3 lysine 27 (H3K27ac and H3K27me3) are associated with bull fertility. Andrologia 2018, 50, e12915. [CrossRef]

27. Kaneda, M.; Okano, M.; Hata, K.; Sado, T.; Tsujimoto, H.; Li, E.; Sasaki, H. Essential role for de novo DNA methyltransferase Dnmt3a in paternal and maternal imprinting. Nature 2004, 429, 900-903. [CrossRef]

28. Marques, C.J.; Francisco, T.; Sousa, S.; Carvalho, F.; Barros, A.; Sousa, M. Methylation defects of imprinted genes in human testicular spermatozoa. Fertil. Steril. 2010, 94, 585-594. [CrossRef]

29. Godmann, M.; Lambrot, R.; Kimmins, S. The dynamic epigenetic program in male germ cells: Its role in spermatogenesis, testis cancer, and its response to the environment. Microsc. Res. Tech. 2009, 72, 603-619. [CrossRef]

30. O'doherty, A.M.; McGettigan, P.A. Epigenetic processes in the male germline. Reprod. Fertil. Dev. 2015, 27, 725-738. [CrossRef]

31. Laqqan, M.; Ahmed, I.; Yasin, M.; Hammadeh, M.E.; Yassin, M. Influence of variation in global sperm DNA methylation level on the expression level of protamine genes and human semen parameters. Andrologia 2020, 52. [CrossRef]

32. Benchaib, M.; Ajina, M.; Lornage, J.; Niveleau, A.; Durand, P.; Guérin, J.F. Quantitation by image analysis of global DNA methylation in human spermatozoa and its prognostic value in in vitro fertilization: A preliminary study. Fertil. Steril. 2003, 80, 947-953. [CrossRef]

33. Khezri, A.; Narud, B.; Stenseth, E.B.; Johannisson, A.; Myromslien, F.D.; Gaustad, A.H.; Wilson, R.C.; Lyle, R.; Morrell, J.M.; Kommisrud, E.; et al. DNA methylation patterns vary in boar sperm cells with different levels of DNA fragmentation. BMC Genom. 2019, 20, 897. [CrossRef] [PubMed]

34. Legendre, A.; Elmhiri, G.; Gloaguen, C.; Magneron, V.; Kereselidze, D.; Saci, N.; Elie, C.; Vaysset, E.; Benadjaoud, M.M.; Tack, K.; et al. Multigenerational exposure to uranium changes morphometric parameters and global DNA methylation in rat sperm. C. R. Biol. 2019, 342, 175-185. [CrossRef] [PubMed]

35. Khadivi, F.; Razavi, S.; Hashemi, F. Protective effects of zinc on rat sperm chromatin integrity involvement: DNA methylation, DNA fragmentation, ubiquitination and protamination after bleomycin etoposide and cis-platin treatment. Theriogenology 2020, 142, 177-183. [CrossRef] [PubMed]

36. González-Marín, C.; Gosálvez, J.; Roy, R. Types, causes, detection and repair of DNA fragmentation in animal and human sperm cells. Int. J. Mol. Sci. 2012, 13, 14026-14052. [CrossRef]

37. Lewis, J.D.; Song, Y.; De Jong, M.E.; Bagha, S.M.; Ausió, J. A walk though vertebrate and invertebrate protamines. Chromosoma 2003, 111, 473-482. [CrossRef]

38. Jodar, M.; Oliva, R. Protamine alterations in human spermatozoa. Adv. Exp. Med. Biol. 2014, 791, 83-102. [CrossRef]

39. Cho, C.; Willis, W.D.; Goulding, E.H.; Jung-Ha, H.; Choi, Y.-C.; Hecht, N.B.; Eddy, E.M. Haploinsufficiency of protamine-1 or -2 causes infertility in mice. Nat. Genet. 2001, 28, 82-86. [CrossRef] 
40. Fortes, M.R.S.; Satake, N.; Corbet, D.H.; Corbet, N.J.; Burns, B.M.; Moore, S.S.; Boe-Hansen, G.B. Sperm protamine deficiency correlates with sperm DNA damage in Bos indicus bulls. Andrology 2014, 2, 370-378. [CrossRef]

41. Simes, R.; Feitosa, W.B.; Mendes, C.M.; Marques, M.G.; Nicacio, A.C.; De Barros, F.R.O.; Visintin, J.A.; Assumpccao, M. Use of chromomycin A3 staining in bovine sperm cells for detection of protamine deficiency. Biotech. Histochem. 2009, 84, 79-83. [CrossRef] [PubMed]

42. Bahreinian, M.; Tavalaee, M.; Abbasi, H.; Kiani-Esfahani, A.; Shiravi, A.H.; Nasr-Esfahani, M.H. DNA hypomethylation predisposes sperm to DNA damage in individuals with varicocele. Syst. Biol. Reprod. Med. 2015, 61, 179-186. [CrossRef] [PubMed]

43. Benchaib, M.; Braun, V.; Ressnikof, D.; Lornage, J.; Durand, P.; Niveleau, A.; Guerin, J.F. Influence of global sperm DNA methylation on IVF results. Hum. Reprod. 2005, 20, 768-773. [CrossRef] [PubMed]

44. Lolis, D.; Georgiou, I.; Syrrou, M.; Zikopoulos, K.; Konstantelli, M.; Messinis, I. Chromomycin A3-staining as an indicator of protamine deficiency and fertilization. Int. J. Androl. 1996, 19, 23-27. [CrossRef]

45. Zandemami, M.; Qujeq, D.; Akhondi, M.M.; Kamali, K.; Raygani, M.; Lakpour, N.; Shiraz, E.S.; Sadeghi, M.R. Correlation of CMA3 Staining with Sperm Quality and Protamine Deficiency. Lab. Med. 2012, 43, $262-267$. [CrossRef]

46. Ni, K.; Spiess, A.N.; Schuppe, H.C.; Steger, K. The impact of sperm protamine deficiency and sperm DNA damage on human male fertility: A systematic review and meta-analysis. Andrology 2016, 4, 789-799. [CrossRef]

47. Steger, K. Transcriptional and translational regulation of gene expression in haploid spermatids. Anat. Embryol. (Berl.) 1999, 199, 471-487. [CrossRef]

48. Francis, S.; Yelumalai, S.; Jones, C.; Coward, K. Aberrant protamine content in sperm and consequential implications for infertility treatment. Hum. Fertil. 2014, 17, 80-89. [CrossRef]

49. Yamauchi, Y.; Riel, J.M.; Ward, M.A. Paternal DNA damage resulting from various sperm treatments persists after fertilization and is similar before and after DNA replication. J. Androl. 2012, 33, 229-238. [CrossRef]

50. Reiter, R.J.; Tan, D.X.; Lorena, F.B. Melatonin: A multitasking molecule. Prog. Brain Res. 2010, 181, $127-151$. [CrossRef]

51. Malama, E.; Bollwein, H.; Taitzoglou, I.A.; Theodosiou, T.; Boscos, C.M.; Kiossis, E. Chromatin integrity of ram spermatozoa. Relationships to annual fluctuations of scrotal surface temperature and temperature-humidity index. Theriogenology 2013, 80, 533-541. [CrossRef] [PubMed]

52. García-Macías, V.; Martínez-Pastor, F.; Álvarez, M.; Borragan, S.; Chamorro, C.A.; Soler, A.J.; Anel, L.; de Paz, P. Seasonal changes in sperm chromatin condensation in ram (Ovis aries), Iberian red deer (Cervus elaphus hispanicus), and brown bear (Ursus arctos). J. Androl. 2006, 27, 837-846. [CrossRef] [PubMed]

53. Piscopo, M. Seasonal dependence of cadmium molecular effects on Mytilus galloprovincialis (Lamarck, 1819) protamine-like protein properties. Mol. Reprod. Dev. 2019, 86, 1418-1429. [CrossRef] [PubMed]

54. Semercioz, A.; Baltaci, A.K.; Mogulkoc, R.; Avunduk, M.C. Effect of Zinc and Melatonin on Oxidative Stress and Serum Inhibin-B Levels in a Rat Testicular Torsion-Detorsion Model. Biochem. Genet. 2017, 55, 395-409. [CrossRef] [PubMed]

55. Pierik, F.H.; Vreeburg, J.T.M.; Stijnen, T.; De Jong, F.H.; Weber, R.F.A. Serum inhibin B as a marker of spermatogenesis. J. Clin. Endocrinol. Metab. 1998, 83, 3110-3114. [CrossRef] [PubMed]

56. Mahmoud, M.A. Protective Effects of Umbelliferone in Experimental Testicular Ischaemia/Reperfusion Injury in Rats. Anat. Physiol. 2016, 6. [CrossRef]

57. Barranco, I.; Fernandez-Fuertes, B.; Padilla, L.; Delgado-Bermúdez, A.; Tvarijonaviciute, A.; Yeste, M. Seminal Plasma Anti-Müllerian Hormone: A Potential AI-Boar Fertility Biomarker? Biology 2020, 9, 78. [CrossRef] [PubMed]

58. Nery, S.F.; Vieira, M.A.F.; Dela Cruz, C.; Lobach, V.N.M.; Del Puerto, H.L.; Torres, P.B.; Rocha, A.L.L.; Reis, A.B.; Reis, F.M. Seminal plasma concentrations of Anti-Müllerian hormone and inhibin B predict motile sperm recovery from cryopreserved semen in asthenozoospermic men: A prospective cohort study. Andrology 2014, 2, 918-923. [CrossRef]

59. La Marca, A.; Sighinolfi, G.; Radi, D.; Argento, C.; Baraldi, E.; Artenisio, A.C.; Stabile, G.; Volpe, A. Anti-Mullerian hormone (AMH) as a predictive marker in assisted reproductive technology (ART). Hum. Reprod. Update 2010, 16, 113-130. [CrossRef] 
60. Fujisawa, M.; Yamasaki, T.; Okada,H.; Kamidono, S. The significance of anti-Mullerian hormone concentration in seminal plasma for spermatogenesis. Hum. Reprod. 2002, 17, 968-970. [CrossRef]

61. Mostafa, T.; Amer, M.K.; Abdel-Malak, G.; Nsser, T.A.; Zohdy, W.; Ashour, S.; El-Gayar, D.; Awad, H.H. Seminal plasma anti-Müllerian hormone level correlates with semen parameters but does not predict success of testicular sperm extraction (TESE). Asian J. Androl. 2007, 9, 265-270. [CrossRef] [PubMed]

62. Duvilla, E.; Lejeune, H.; Trombert-Paviot, B.; Gentil-Perret, A.; Tostain, J.; Levy, R. Significance of inhibin $\mathrm{B}$ and anti-Müllerian hormone in seminal plasma: A preliminary study. Fertil. Steril. 2008, 89, 444-448. [CrossRef] [PubMed]

63. Capra, E.; Lazzari, B.; Turri, F.; Cremonesi, P.; Portela, A.M.R.; Ajmone-Marsan, P.; Stella, A.; Pizzi, F. Epigenetic analysis of high and low motile sperm populations reveals methylation variation in satellite regions within the pericentromeric position and in genes functionally related to sperm DNA organization and maintenance in Bos taurus. BMC Genom. 2019, 20, 940. [CrossRef] [PubMed]

64. Rahiminia, T.; Yazd, E.F.; Fesahat, F.; Moein, M.R.; Mirjalili, A.M.; Talebi, A.R. Sperm chromatin and DNA integrity, methyltransferase mRNA levels, and global DNA methylation in oligoasthenoteratozoospermia. Clin. Exp. Reprod. Med. 2018, 45, 17-24. [CrossRef]

65. Montjean, D.; Zini, A.; Ravel, C.; Belloc, S.; Dalleac, A.; Copin, H.; Boyer, P.; McElreavey, K.; Benkhalifa, M. Sperm global DNA methylation level: Association with semen parameters and genome integrity. Andrology 2015, 3, 235-240. [CrossRef]

66. Houshdaran, S.; Cortessis, V.K.; Siegmund, K.; Yang, A.; Laird, P.W.; Sokol, R.Z. Widespread epigenetic abnormalities suggest a broad DNA methylation erasure defect in abnormal human sperm. PLOS ONE 2007, 2, e1289. [CrossRef]

67. Verma, A.; Rajput, S.; De, S.; Kumar, R.; Chakravarty, A.K.; Datta, T.K. Genome-wide profiling of sperm DNA methylation in relation to buffalo (Bubalus bubalis) bull fertility. Theriogenology 2014, 82, 750-759. [CrossRef]

68. Hamad, M.F.; Dayyih, W.A.A.; Laqqan, M.; AlKhaled, Y.; Montenarh, M.; Hammadeh, M.E. The status of global DNA methylation in the spermatozoa of smokers and non-smokers. Reprod. Biomed. Online 2018, 37, 581-589. [CrossRef]

69. David, I.; Kohnke, P.; Lagriffoul, G.; Praud, O.; Plouarboué, F.; Degond, P.; Druart, X. Mass sperm motility is associated with fertility in sheep. Anim. Reprod. Sci. 2015, 161, 75-81. [CrossRef]

70. David, I.; Kohnke, P.; Fehrenbach, J.; Lopes Simoes, A.R.; Debreuve, E.; Descombes, X.; Plouraboue, F.; Degond, P.; Druart, X. New objective measurements of semen wave motion are associated with fertility in sheep. Reprod. Fertil. Dev. 2018, 30, 889. [CrossRef]

71. Aydos, O.S.; Yükselten, Y.; Kaplan, F.; Sunguroğlu, A.; Aydos, K. İnfertil erkeklerde sperm DNA bütünlüğü ve konvansiyonel semen parametreleri arasındaki korelasyonun analizi. Turk. Urol. Derg. 2015, 41, 191-197. [CrossRef]

72. Elbashir, S.; Magdi, Y.; Rashed, A.; Ibrahim, M.A.; Edris, Y.; Abdelaziz, A.M. Relationship between sperm progressive motility and DNA integrity in fertile and infertile men. Middle East. Fertil. Soc. J. 2018, 23, 195-198. [CrossRef]

73. Huang, C.C.; Lin, D.P.C.; Tsao, H.M.; Cheng, T.C.; Liu, C.H.; Lee, M.S. Sperm DNA fragmentation negatively correlates with velocity and fertilization rates but might not affect pregnancy rates. Fertil. Steril. 2005, 84, 130-140. [CrossRef] [PubMed]

74. Snyder, P.J. Effects of Age on Testicular Function and Consequences of Testosterone Treatment. J. Clin. Endocrinol. Metab. 2001, 86, 2369-2372. [CrossRef] [PubMed]

75. Ruiz-Olvera, S.F.; Rajmil, O.; Sanchez-Curbelo, J.-R.; Vinay, J.; Rodriguez-Espinosa, J.; Ruiz-Castañé, E. Association of serum testosterone levels and testicular volume in adult patients. Andrologia 2018, 50, e12933. [CrossRef]

Publisher's Note: MDPI stays neutral with regard to jurisdictional claims in published maps and institutional affiliations. 